\title{
Letter
}

\section{Tuna regional fisheries management organizations and the conservation of sea turtles: a reply to Godley et al.}

Fisheries bycatch, in particular in tuna and tuna-like fisheries, is one of the main causes of sea turtle declines (Lewison et al., 2014). Godley et al. (2020) described some of the actions being carried out internationally for the sea turtle conservation. Although they acknowledged there have been efforts to understand the effects of commercial fisheries bycatch, they did not address ongoing initiatives for sea turtle bycatch. Here, we outline actions taken by tuna regional fisheries management organizations.

Scientific advice and the management of fisheries targeting tuna and tuna-like species are provided by tuna regional fisheries management organizations. In chronological order by founding, these are the Inter-American Tropical Tuna Commission (1949), the International Commission for the Conservation of Atlantic Tunas (1966), the Indo-Pacific Tuna Program (prior to 1980), the Indian Ocean Tuna Commission (1993), and the Western and Central Pacific Fisheries Commission (2004). These organizations, supported by their respective Scientific Committees, cover all the oceans and main seas (including most sea turtle ranges), are intergovernmental, and are responsible for data collection, monitoring and management of tuna and tuna-like resources, including associated bycatch.

The scientists working with these organizations provide annual information on turtle bycatch. There have been several recent initiatives, including impact assessments ( $\mathrm{Nel}$ et al., 2013; Angel et al., 2014; Williams et al., 2018) and bycatch mitigation measures for pelagic fisheries management (Coelho et al., 2013). An example is the work of some contracting parties collaborating in the identification of sea turtle bycatch patterns in longline and purse seine tuna fisheries in the Atlantic Ocean, Mediterranean Sea and South Indian Ocean (Anon., 2020). Similarly, there have

Juan Antonio Camiñas (B) orcid.org/0000-0002-8095-073X) Asociación Herpetológica Española, Madrid, Spain

ANDRÉs Domingo (D orcid.org/0000-0002-1793-7663) Laboratorio de Recursos Pelagicos, Dirección Nacional de Recursos Acuáticos, Ministerio de Ganadería Agricultura y Pesca, Montevideo, Uruguay

Rui Coelho (iD orcid.org/0000-0003-3813-5157) Portuguese Institute for the Ocean and Atmosphere, Olhão, Portugal

Paul De Bruyn (D) orcid.org/0000-0002-6015-076X) Indian Ocean Tuna Commission, Victoria, Seychelles

Francisco Abascal (D orcid.org/0000-0002-8550-8617) Instituto Español de Oceanografía, Tenerife, Spain

Jose CARLos BAÉZ (Corresponding author, (D) orcid.org/0000-0003-2049-0409) Instituto Español de Oceanografía, Fuengirola, Spain

E-mail josecarlos.baez@ieo.es

First published online 9 November 2020 been a number of studies within the framework of other tuna regional fisheries management organizations, ranging from the initiatives of individual research groups to coordinated basin-scale or global initiatives. These efforts are illustrated by the Bycatch Mitigation Information System, launched by the Western and Central Pacific Fisheries Commission and later expanded and supported by the FAO Common Oceans Tuna Project (Fitzsimmons et al., 2019).

To continue reducing bycatch of non-target species, including sea turtles, the first joint tuna Regional Fisheries Management Organization Bycatch Working Group meeting was organized in December 2019 in Porto, Portugal, to rejuvenate the process of coordination between the organizations on bycatch issues (Anon., 2019).

\section{References}

Angel, A., Nel, R., Wanless, R.M., Mellet, B., Harris, L. \& WiLson, I. (2014) Ecological risk assessment of sea turtles to tuna fishing in the ICCAT region. Collective Volume of Scientific Paper ICCAT, 70, 2226-2259.

Anon. (2019) Chair's Report of the 1st Joint Tuna RFMO By-Catch Working Group Meeting (16-18 December 2019, Porto, Portugal). iccat.int/Documents/meetings/docs/2019/reports/2019_JWGBYCATCH_ENG.pdf [accessed 9 October 2020].

Anon. (2020) Report of the 2nd Workshop on Collaborative Work to Assess Sea Turtle Bycatch in Pelagic Longline Fleets (Atlantic and Indian Oceans and Mediterranean Sea). SCRS/2020/04O. International Commission for the Conservation of Atlantic Tunas, Madrid, Spain.

Coelho, R., Fernandez-Carvalho, J. \& Santos, M.N. (2013) A review of sea turtle mitigation measures across the five tuna RFMO and other fisheries management organizations. Collective Volume of Scientific Paper ICCAT, 69, 1860-1866.

Fitzsimmons, L., Abraham, E., Caillot, S. \& Smith, N. (2019) An Update on the Bycatch Management Information System (BMIS): Developments in 2018-19 Including the Integration of Data Visualisation and Mapping for Bycatch Data. In WCPFC Scientific Committee 15th Regular Session. WCPFC-SC15-2019/EB-IP-01, Pohnpei, Federated States of Micronesia.

Godley, B.J., Broderick, A.C., Colman, L.P., Formia, A., Godfrey, M.H., Hamann, M. et al. (2020) Reflections on sea turtle conservation. Oryx, 54, 287-289.

Lewison, R.L., Crowder, L.B., Wallace, B.P., Moore, J.E., Cox, T., ZYDELIS R. et al. (2014) Global patterns of marine mammal, seabird, and sea turtle bycatch reveal taxa-specific and cumulative megafauna hotspots. Proceedings of the National Academy of Sciences of the United States of America, 111, 5271-5276.

Nel, R., Wanless, R.M., Angel, A., Mellet, B. \& Harris L. (2013) Ecological Risk Assessment and Productivity-Susceptibility Analysis of Sea Turtles Overlapping with Fisheries in the IOTC Region. 9 th Working Party on Ecosystems and Bycatch, Indian Ocean Tuna Commission, La Réunion, France. iotc.org/sites/default/files/documents/2014/o1/IOTC2013-WPEBo9-23_-_Marine_turtle_ERA.pdf [accessed 9 October 2020].

Williams, A.J., Georgeson, L., Summerson, R., Hobday, A., Hartog, J., Fuller, M. et al. (2018) Assessment of the Vulnerability of Sea Turtles to IOTC Tuna Fisheries. 14th Working Party on Ecosystems and Bycatch, Indian Ocean Tuna Commission, Cape Town, South Africa. iotc.org/sites/default/files/documents/2018/o8/ IOTC-2018-WPEB14-40.pdf [accessed 9 October 2020]. 